\title{
TOWARDS AN INTERPRETATION OF THE PHENOMENA OF DEMON POSSESSED/DEMONIZED CHRISTIANS
}

\author{
GANI WIYONO
}

\section{INTRODUCTION}

In the pre-modern world people generally believed in the supernatural. Individuals and culture as a whole believed in the existence of God (or gods), angels, and demons. The visible world owed its existence and meaning to a spiritual realm beyond the senses. However, such worldviews began to die with the coming of Enlightenment of $17^{\text {th }}$ and $18^{\text {th }}$ centuries. The age of reason, scientific thinking, and human autonomy that characterized the Enlightenment brought to being the so-called natural religion. The result was the disappearance of immanent God (Deism) and the rejection of the socalled "excluded middle" 41 - the unseen world of spirits, and the supernatural. Such attitude may well be summarized in Rudolf Bultmann' famous statement: "It is impossible to use electric light and the wireless and to avail ourselves of modern medical and surgical discovers, and at the same time to believe in the New Testament worlds of spirits and miracles."42

However the collapse of modern culture with its materialistic naturalism that happened recently has made the pendulum swing from one extreme to another. There has been such a great awakening of the supernatural almost in every dimension of contemporary society. Inside the ecclesiastical setting, the Pentecostal-charismatic movement that puts much

41 This term is firstly coined by Paul G. Hiebert, "the Flaw of the Excluded Middle," Missiology: An International Review (January 1982): 35-47. Reprinted in Paul G. Hiebert, Anthropological Reflections on Missiological Issues, (Grand Rapids, MI: Baker Book, 1994), 189-201.

42 Rudolf Bultmann, "New Testament and Mythology," in Kerygma and Myth, edited by H. W. Bartsch, and revised by Reginald H. Fuller (London: SPCK, 1961), 5. 
emphasis on the presence and supernatural works of the Spirit of God in the natural realm has grown fantastically around the globe.43 While outside the ecclesiastical setting, the New Age Movement that promotes extraordinary experiences with the supernatural has enjoyed wider acceptance.

As a result of such awakening, "the language of the demonic" has been reinstated in everyday-life conversations, both inside and outside the ecclesiastical setting. Frank Peretti's This Present Darkness and Piercing the Darkness 44 have taught church members to learn the language of spiritual warfare. TV serials such as the Millennium, X-Files, Charmed, and Buffy the Vampire Slayer have aroused such an awareness of the demonic intervention in our every-day life. Secular psychiatrists begin to reconsider the demonic influence as a possible cause of severe Dissociative Identity Disorders (DID) and to learn how to deal with it in such a holistic way.

Turning to a specific group within the Pentecostal-charismatic movement, the so-called "The Third Waver,"45 we find such an extreme interpretation of the demonic seldom found among classical Pentecostals46 or even charismatics. The Third Wavers generally not only believe that the

43 David B. Barrett and Todd M. Johnson, “Annual Statistical Table on Global Mission: 2000," International Bulletin 50th Anniversary (January 2000): 25 estimate that there are more than 523,767,000 Pentecostals/Charismatics around the globe.

44 John Seel, The Evangelical Forfeit (Grand Rapids, MI: Baker Book, 1993), 43, notes that Peretti’ This Present Darkness (1986) and Piercing the Darkness (1989) together have sold over 3 millions copies since their release.

45 Peter Wagner has coined the term "the Third Wave" to describe mainline evangelicals who exercise spiritual gifts and emphasizes signs and wonders, but who do not identify with either classical Pentecostals or charismatic movements. Wagner says, "I do not consider myself a charismatic. I am simply an evangelical Congregationalist who is open to the Holy Spirit working through me and my church in any way he chooses. “ For a greater detail see C. Peter Wagner, The Third Wave of the Holy Spirit: Encountering the Power of Signs and Wonders Today (Ann Arbour: Vine Books, 1988).

46Andrew Walker, "The Devil You Think You Know" in Charismatic Renewal (London: SPCK, 1995), 90, explain why classical Pentecostalism is not wholly occupied with the demonic. First, "it was essentially evangelistic in nature ... Its evangelism therefore kept it outward-looking and Christ-centered, leaving its demonism in the wake of its excitement and enthusiasm. It was there alright, but it was peripheral and virtually out of sight." Second, Pentecostals "were too entranced with their own Pentecost - with its tongues, healings, and sing along songs - to be bewitched by beguiling theories of demonism." Third, Pentecostals "may have been educationally disadvantaged, but they were not stupid. What they lacked in cultural finesse they made up with working-class common sense" 
believers can be attacked by demons but also be demonized or demonpossessed.

Since such interpretation of the demonic has created a great deal of debate47 and even confusion among church members (even church ministers), I am motivated to do such a critical response. Therefore, in this paper I will attempt to identify the arguments used as support for the assertion that a born-again believer can be demon-possessed (or demonized) and then will critically evaluate them primarily in the light of exegetical and theological studies. In the end, I will include a proposal concerning a better way of interpreting such a phenomena (demon-possessed believers) by utilizing such integrative (biblical-theological-empirical) approach. 


\section{THE ANTECEDENTS OF THIRDWAVERS' BELIEF OF THE DEMONIZATION OF CHRISTIANS}

Before Charles Kraft, Fred Dickason, Peter Wagner and other Thirdwavers propagated the belief of the demonization of Christians, there were some people in the Christian history who held the similar ideas. The way they argue for such belief are not necessarily identical with they way Kraft, or Dickason, or Wagner argues. The following is a brief presentation of some significant figures who preceded the thirdwavers in believing in the demonization of believers.

\section{Before the 20th Century}

Perhaps the earliest document that suggests the possibility that Christian could be demonized is the Shepherd of Hermas. In this particular document which was circulated in both in the Eastern and Western Church (shortly before or after the middle of the Second Century), the author wrote: “...For the Lord dwells in long suffering, but the Devil in anger. The two spirits, then when dwelling in the same habitation, are at discord with each other, and are troublesome to that man in whom they dwell."48

Origen (185-254 C.E.), one of the most prominent theologians before the Council of Nicea, spoke of the authority of believers to drive demons out of themselves. In Homily on Joshua 5.5, he wrote, ' anyone who vanquishes a demon in himself e.g. the demon of lewdness, puts it out of action; the demon is casted into the abyss and cannot do any harm to anyone."49 Eusebius, the early church historian, mentioned the testimony of Cornelius (250 C.E). a Roman bishop, who narrated a deliverance ministry practiced over "a convert, named Novatus, a future presbyter in the Roman church, 
after a spirit 'entered into him and stayed within him for a considerable time,' causing him to become desperately ill."50

Clinton Arnold mentions that throughout the post-Nicene age, the Byzantine Empire, the Middle Ages, and the Reformation era, there are numerous accounts that suggest that Christians could be profoundly influenced by the demons. 51 Whether such influences can be considered demon-possessed or demonized are hardly verified.

\section{.During the $20^{\text {th }}$ Century}

The first modern-day figure who revived the doctrine of demonpossessed believers is Jesse-Penn Lewis, who befriended one of the great leaders of the Welsh revival (1904). In a book entitled War on the Saints, she wrote, "believers, - true fully surrendered children of God, can be deceived and then up to degree of deception, "possessed by the deceiving spirits ..."52 This particular book was denounced and banned by the Pentecostal churches that generally reject the belief of the demonization of believers.

After the World War II, A.A. Allen (1911-1970) gained prominence as a minister who advanced the idea that believers could have a demon. His typical prayer ran: "I pray, purify me from all the evils that cling to me ... Bind all powers that whispers temptation and eavesdrop, and the calling of magical powers..."53 Like Jesse-Penn Lewis, he was eventually disowned by the established Pentecostal church.54

Following Allen, came the Fort Laudardale Five (FLF), " a group of individuals, largely from a Pentecostal background, who came together on the basis of a number of common theological interests. Two of the FLF's key

50 Eusebius, Church History, 6. 43 as quoted in Arnold, 112.

51Ibid., 112.

52 Jesse Penn-Lewis, War on the Saints, $9^{\text {th }}$ ed. (New York: Thomas Lowe, 1973), 68.

53Quoted in Stephen Hunt, "Deliverance: The Evolution of a Doctrine," Themelios (October 1995): 11.

54Ibid., 11. 
leaders, Don Basham and Derek Prince significantly advanced of the belief of the demonization of Christians in the 1970s. Basham, most likely under the influence of the healing evangelist Maxwell White, spoke about the deliverance of believers from a demon of asthma and a demon of smoking as evidenced by the act of vomiting.55 Derek Prince, is responsible for developing teachings of territorial spirits, "ancestral spirits, and the alleged demonic implications of self-curses, generational curses and 'soulish prayers', through his very influential work Blessing or Curse."56

Following the FDL's footsteps, came Frank and Ida Mae Hammond, with their disturbing work, Pigs in the Parlour. This work had a significant influence in North American, England, and New Zealand. Bill Subritzky, whose deliverance ministry has had the greatest impact upon the Anglican in Great Britain undoubtedly is one of those who resounded and resonated Hammonds' teaching .57

In the 1970s, a belief of the demonization of believers began penetrating the scholarly-world. Merril F. Unger, a biblical scholar from Dallas Theological Seminary, John W. Montgomery, Professor of Jurisprudence at the Simon Greenleaf School of Law, Orange, California and one of the leading theologian of that decade, Kurt Koch, a German theologian, are among those who embrace such "unorthodox" teaching.58 Those people who are basically evangelicals, but not necessarily Pentecostal/charismatics have a significant influence on the development of Thirdwavers' doctrine of the demonization of believers.

55Ibid., 12.

56Ibid, 12.

57Walker, 91.

58Kurt Koch, Occult bondage and Deliverance: Advice for Counseling the Sick, the Troubled, and the Occult Oppressed (Grand Rapids, MI: Kregel Publication, 1970), 67-71; John W. Montgomery, "Commentary on Hysteria and Demons, Depression and Oppression, Good and Evil," in Demon Possession, edited by John W. Montgomery (Minneapolis, MN: Bethany House Publisher, 1976), 232-235; Unger, What Demons Can Do to Saints, 149-167. 


\section{THE THIRDWAVERS' ARGUMENTS FOR A DOCTRINE OF THE DEMONIZATION OF CHRISTIANS}

\section{Experience Taking Priority over Biblical Exegesis}

Certainly the Thirdwavers" "doctrine " of a demon-possessed Christian did not originate in a biblical or theological class, as the Classical Pentecostals' doctrine of tongue as initial physical evidence did.59 Its genesis was stimulated by empirical experiences, as Charles H. Kraft, a major proponent of the demonization of believers, boldly says:

As EVANGELICALS, we are committed to accepting whatever the Bible asserts. But understanding precisely what it says is often difficult. For example, for years ... I believed that the following biblical verse and several others proved that Christians could not be demonized: "But you belong to God, my children, and have defeated the false prophets, because the Spirit who is in you is more powerful than the spirit in those who belong to the world." (1 Jn 4:4).

I believe this Scripture. And I wish with all my heart that my earlier interpretation of it were right, that Christians cannot be demonized. But experience has shown me that the verse cannot mean that the presence of the Holy Spirit makes it impossible for dark angels to live in them. The process by which I free persons from demons proves the truth of this verse over and over, but I have had to consider my first interpretation of it. 60

59 William W. Menzies, Anointed to Serve (Springfied, MO: Gospel Publishing House, 1971), 39 writes, “...in Topeka, it ... seems to be the first time that the phenomenon of speaking with tongues, glossolalia, was related to the experience of the baptism in the Holy Spirit as the initial physical evidence... It is significant that this thought developed, not in revival meeting, but in Bible school, not in the midst of camp meeting excitement, but in a group of serious persons who were pondering thoughtfully the relationship of this experience to other events, attempting to give it theological substance." mine.

60 Charles H. Kraft, Defeating Dark Angels (Ann Arbor, MI: Servant Publication, 1992), 61, emphasis 
Another influential person in propagating the doctrine of demonization of believers, C. Fred Dickason, the chairman of the theology department at Moody Bible Institute in Chicago, has a similar conclusion. He says that indeed it is difficult to answer the question, "Can Christian be demonized?" from biblical research alone since the Bible seems to be "silent" on this particular subject. Thus, according to Dickason we need another kind of evidence - clinical evidence, to solve that problem.61 Based on many case studies from counseling of the demonized, he concludes: "...clinical evidence found by qualified counselors has helped us answer in the affirmative the question, Can genuine believers in Christ be inhabitted by demons?"62

\section{"Demonized" instead of "Demon Possessed"}

Thirdwavers are usually reluctant to use the words "demon possessed"; they would rather to use the word "demonized". For them, this term more accurately captures the essence of biblical teaching that provides "no room" for the idea that born-again believers could be totally controlled by demons.63 The term "demonized" on the other hand provides a good explanation to born-again believers having demonic symptoms.

Clinton Arnold, New Testament professor of Talbot School of Theology, later substantiates the usage of the term "demonized." He argues that "the word possession never appears in the Bible where Jesus or the apostle casts evil spirits out of an individual" because the Greek word, daimonizomai which is traditionally translated into English word, "demonpossessed", does not convey the idea of ownership or possession, but description of person tormented, vexed, or troubled by demons.64 If the 149-167.

61 C. Fred Dickason, Demon Possession and the Christian (Wheaton, IL: Crossway Books, 1987):

62Ibid., 213.

63 Kraft, 63, 66-67.

64 Arnold, 79-80. 
intended meaning is "demon possessed", the Greek verb used should be either huparcho, echo, katecho, ktaomai, or peripoieo.65

Arnold also argues that modern understanding of the English word "possess" which may convey the notion of ownership is misleading. He says, "But it is also important to realize that the English term possess has a long history of usage where the emphasis could fall on control and occupancy as opposed to ownership."66

So, what is the meaning of "demonization" if it ought not be understood in the notion of ownership? For Dickason it means, " a demon caused passivity or control due to a demon's residing within a person, which manifests its effect in various physical and mental disorders and in varying degrees." 67 However, it does not mean that demons permanently indwell born-again believers; they are merely "squatters or invaders of territory does not belong to them."68

\section{"Partitive Anthropology" as A Solution to Theological Problem}

Such understanding consequently brings a theological problem since it implies that demons are capable of cohabiting with the Holy Spirit within a born-again believer. To solve this theological difficulty, some Thirdwavers basically follows Merril F. Unger's ‘tripartite anthropology'. Merrill F. Unger believes that human being consists of spirit, soul, and body. 69 The Holy Spirit exclusively indwells in the 'spirit' of born-again believer; and so demons are not capable of cohabiting with the Spirit in their innermost

65 Ibid., 79.

66 Ibid., 80.

67 Dickason, 40.

68 Ibid., 38.

69 Unger, What Demons Can Do to Saints, 86. 
being.70 However, demons may "invade and cause upheaval and chaos in the believers through his body and soul."71

Charles Kraft modifies Unger's argument. His starting point is not tripartite anthropology, but dualistic, semi-platonic anthropology.72 He believes that human being consists of the innermost part (spirit) and "the outer parts" (mind, emotions, body, and will). A renewed spirit is considered as purer than mind, emotions, will, and body. Consequently, demons never gain access to the innermost part of human being, since it is "joined to and filled with the Holy Spirit (Roma 8:16)."73 But they can "live in a Christian's mind, emotions, body and will."74

Kraft's theory further is sharpened by Clinton Arnold. He argues that human being consists of the core and 'the margin'. While, the core signifies "the center of his or her being, his or her ultimate nature and identity,"75 the 'margin' spells out his or her mind, will, and emotions. When a person becomes a born-again believer, he or she becomes a new creature (2 Cor $5: 17)$. His or her old core identity which is corrupt, belongs to present evil age, and destined for death and wrath is transformed into new core identity, which is pure and holy, belongs to age to come, destined for life, and is indwelled by the Holy Spirit.76 Such a fundamental change however does not instantly transforms person's mind, will, and emotions. It takes a gradual, progressive, and lifetime process to be image of God.

70 Ibid., 87.

71 Ibid., 87.

72 The terms, "dualistic, semi-platonic" is chosen because there is striking similarity between KraftArnold's anthropology and Platonic anthropology. Both consider spirit as purer than anything else. The difference is Platonic anthropology speaks of "spirit-body" dichotomy, while Kraft-Arnold's anthropology speaks of "spirit-psychosomatic" dichotomy.

73 Kraft, 67.

74 Ibid., 67.

75 Arnold, 85

76 Ibid., 83-84 
In such process, a born-again believer faces difficulties due to the presence of $\sin$ (evil influences) that manifests in three forms: the flesh (evil inclination), the world (environment culture) and the devil (demons). Since sin may reign over a mortal body (Rom 6:12), demons that are one of these manifestations of sin may also "reign" in the life of a born-again Christian.77 In other words, Arnold believes that demons "can dominate and ... can control ... will take as much governing powers as we will allow them to take."78

\section{A CRITICAL EVALUATION ON THE THIRDWAVERS' DOCTRINE OF THE DEMONIZATION OF GENUINE CHRISTIANS}

A critical evaluation on the Thirdwavers' doctrine of the demonization of genuine Christians will be given in the following paragraphs. Firstly, it will pinpoint the problems of experience-based theology. Secondly, it will show the problems of using the word "demonized" to depicts the phenomena of demon-possessed believers. Thirdly, it will demonstrate that "partitive anthropology" which is often used by the defenders of the doctrine of demon-possessed believers is such a distorted reading on the biblical anthropology.

\section{Giving Experience Its Due}

It is true that real-life experience play important role for developing theology. As William W. Menzies says, "Theology that has little or no relevance for live as it is lived in the kitchen or the market place may be a

77 Ibid., 89-90.

78 Ibid., 91. 
pleasant academic diversion, but it bears little resemblance to the theology of the biblical writers."79

If it is mishandled however experience may produce a distorted theology. Such distortion may happen primarily due to the nature of experience itself. First, "a language of experience is by definition a plural language, since no two persons describe their lives in the same terms unless they have been forced into a unified language."80 Second, as Alister McGrath has noted, "experience is not pre-theoretical data, but is actually theory-ladden: it is accompanied by interpretive elements," 81 meaning that "prior knowledge and belief plays a constitutive role in determining what we observe and experience." These facts should make us be cautious in using experience for developing theology.

So, how do we utilize experience in theologizing process? The best answer for this question may be found in William Menzies' methodology. Menzies argues that experience does not establish theology, but verifies and demonstrates theological truth, found in the inductive (exegesis) and deductive (biblical theology) study of the Scripture.82 As a concrete illustration of his methodology, Menzies mentions what happened in Topeka Kansas in 1900-01.

It was the inductive study of the Bible that led the students at Bethel Bible School in Topeka Kansas in 1900-01 to expect a baptism in the Spirit with the accompanying sign of speaking in tongues, When they in fact experienced precisely what they thought the Bible was teaching, they ere then able to affirm the continuity between biblical concept and existential reality, Their whole understanding of the

79William W. Menzies, "The Methodology of Pentecostal Theology: An Essay on Hermeneutics," in Essay om Apostolic Themes: Studies in Honor of Howard M. Ervin Presented to him by Colleagues and Friends on his Sixty-Fifth Birthday,” edited by Paul Elbert (Peabody, MA: Hendrickson Publishers, 1985), 13.

80 In Jean-Daniel Pluss, Therapeutic and Prophetic Narratives in Worship. Studies in the Intercultural History of Christianity Band 54 (Frankurt: Verlag Peter Lang, 1988), xviii.

81Alister E. McGrath, The Genesis of Doctrine: A Study in the Foundation of Doctrinal Criticism (Grand Rapids, MI: Wm. B, Eerdmans, 1997), 71.

82See Menzies, The Methodology of Pentecostal Theology, 5-13. 
apostolic church was transformed. They discovered a synthesis of truth at the inductive level, at the deductive level, and at the verificational level!83

Charles Kraft and Fred Dickason are guilty of giving personal experience priority over a careful inductive and deductive study of the Scripture. Thinking in such a pragmatic framework, "since it works in clinical experiences, it must be true," Kraft and Fred Dickason treat personal experience as the "origination" of theology. This, of course, is nothing but a repetition of Scheiermacher's flaws! - something which is rejected by evangelicals.

Dickason may argue that clinical evidence should be used as the origination of theology, since the Bible seems to be silent on the particular subject (demon possessed/demonized believers).84 Dickason's judgment seems to be premature. It may be true that there is no declarative statement expressed in the Scripture regarding the impossibility of believers to be demonized or demon-posssessed. There however are some biblical texts whose implications are that there is impossible for believers to be demonized or demon-possessed ( 1 Jn 4:4; Col 1:13; Eph 2:2; 2 Cor 6:16).85

\section{The Language Game of Demonic Influence}

Is the choice of the word, 'demonized' for describing the phenomena of demon-possessed believers worth taking?" The answer seems not to be affirmative! First, major Greek-English Lexicons and Theological dictionaries have used "demon possessed" for translating the Greek word, daimonizomai.86 Second, a suggestion that words for possession, such as

83Ibid., 13.

84See Dickason, 149-67.

85See W Duane Collins, “An Assemblies of God Perspective on Demonology Part II," Paraclete 28:1 (Winter 1994): 20, 22. 
huparcho, echo, katecho, ktaomai, or peripoieo should be used instead of daimonizomai, fails to recognize that Luke does use echei daimonion (4:33; 8:27).87 Third, a claim that the word daimonizomai which occurs 13 times in the New Testament (all in the Gospels: Matt. 4:24; 8:16, 28, 33; 9:32; 12:22; 15: 22; Mark 1:32; 5:15, 16, 18; Luke 8:36, and John 10:21) does not convey a sense of total control or ownership, but a various degree of demonic influence, must skip the account of Gerasane demoniac (Mat 8: 28, 33; Mark 5: 15, 15, 18; Luke 8:36), due to the fact that account provides a case of typical demon possession. 88

Furthermore, the word "demonized" in English suggests very strong demonic influence or control. As Grudem has noted, similar 'ized' words, such as "pasteurized, homogenized, tyrannized, materialized, nationalized, etc, ... all speak of a total transformation of the object spoken about, not simply of mild or moderate influence." 89

Thus, we can say that even though the word "demonized" may provide "a useful bridge" to connect demonic symptoms found in the life of a bornagain believer to a traditional understanding that a born again believers

86 See, Exegetical Dictionary of the New Testament, s.v. "daimonion, daimon" by 0. Bocher; Harold K. Moulton, The Analytical Greek Lexicon. rev. ed. (Grand Rapids, Ml: Zondervan Publishing House, 1978), 84; Theological Dictionary of the New Testament, s.v. "daimon, daimonion, daimonizomai, daimoniodes, deisidaimon, deisidaimonia," by Werner Foerster; Walter Bauer, A Greek-English Lexicon of the New Testament and Other Early Christian Literature, translated by William F. Arndt and F. Wilbur Gingrich (Chicago: University of Chicago Press, 1979), 169; Joseph H. Thayer, Thayer's Greek-English Lexicon of the New Testament (Grand Rapids, MI: Baker, 1977), 128.; NewInternational Dictionary of New Testament Theology, s.v. "daimonion," by H. Bietenhard. Cf. Stephen Carter, "Demon Possession and Christian," Asia Journal of PentecostalTheology (January 2000): 19-31.

87 Arnold, 205, argues that echei daiomonion (he has a demon) should be differentiated from daimon echei auton (a demon has him). While the later has a strong sense of ownership, the former does not. Such "grammatical game" may be valid for impersonal being, but it does not work for personal being. "I have a child" is not much different from "a child has me" if the context refers to the same child. There is extensive biblical evidence that a demon is personal being (for example: the usage of personal pronouns, personal name applied to a demon by Christ (Luk 8:27-30), the notion that demons has intelligence (Mk. 1:23-24), will (Luk 8:32), and emotions (Luk 8:28))

88 See William L. Lane, The Gospel According to Mark. New International Commentary on the New Testament, edited by F.F. Bruce (Grand Rapids, MI: Wm. B. Eerdmans Publishing Co., 1974), 179-191.

89 Wayne Grudem, Systematic Theology: An Introduction to Biblical Doctrine (Grand Rapids, MI: Zondervan Publishing House, 1994), 423. 
cannot be demon possessed," it still has serious flaws. First, it seems to carry extra-biblical meaning that is most probably alien to the biblical authors. Second, even if the word "demonized" could be used, it inherently carries the meaning that is not significantly different from "demonpossessed".

\section{Distorted Anthropology}

As being described above, the advocates of "a demonized/demon possessed believer" generally develop "partitive" anthropology to substantiate their thesis. At a glance, such view seems to gain much support from the Scripture. However if one looks more carefully, he or she would see instead of viewing human being partitively, the Bible conceives human being aspectively. This means that instead of regarding human being as made up of distinct part (body, soul, and spirit (Unger) or spirit and mind, will, emotions (Kraft and Arnold)) the Bible tends to conceive human being as a whole person existing on different dimension. First Thes. 5:23 for example, which is oft quoted to substantiate a partitive trichotomy of "spirit, soul and body", comes in the context emphasizing wholeness in sanctification.90 Another text, Deuteronomy 6.5, indeed mentions, " heart, soul, and might" but it emphasizes the totality of commitment to serve God.

A more sounding partitive, semi platonic dichotomy of the "core" (innermost part - spirit) and the margin (psychosomatic- body, mind, will, emotions) developed by Kraft and Arnold may sound more biblical than partitive trichotomy. However, looking at biblical data carefully will immediately show its serious flaws. Second Cor. 7: 1, for example, which speaks Paul's exhortation to the Corinthians to cleanse themselves "from every defilement of body and spirit", clearly implies that there can be defilement (or sin) in spirit. This consequently destroys Kraft and Arnold's thesis - that the "core" as purer than the "margin," and when transformed, as totally free from and untouchable by $\sin$.

90 Mark 12:30, poses a question to three partite anthropology, if it is interpreted literally in the same manner as 1 Thes. 5:23. Here, human being is not considered as having three, but four components, namely heart, soul, mind, and strength (which implies the body). 
The on-going, progressive renewal of the inner-man mentioned in 2 Cor 4:16 also puts Arnold's thesis on the perfect status of a renewed spirit into question. The Inner-man Paul referring here undoubtedly speaks of the totality of Christian existence as a new creature that includes person's mind, will, emotions and certainly spirit and body.91 Thus, elevating a renewed spirit to the status of "the untouchable by sin" seems to be more platonic than biblical. 


\section{TOWARDS AN INTERPRETATION OF THE PHENOMENA OF DEMON-POSSESSED/DEMONIZED BELIEVERS}

First of all we need to consider that even though the theological rationale given by the advocates of demonized believers may be naïveté, the seemingly demonic phenomena themselves may be genuine, not just "the product of a hyperactive imagination or of a supercharged atmosphere."92 Thus the far-reaching question is not whether the phenomena reported is genuine or not but how we can interpret those phenomena properly within the framework of Christian theology.

To answer this far-reaching question satisfactorily we must acknowledge that there is a wide range of personal human disorders. The third wavers who allow only one of interpretation: demons, as the source of personal human disorders are guilty of being reductionists. They fail to recognize the complexity of human being. Is it coincidence that Paul employs a rich vocabulary in speaking about human being, even though his basic perspective is always the whole person?93 Did he realize that human being is psychologically, psychically, socially and spiritually complex? It seems so! Thus, even though the seemingly demonic symptoms is present within the so-called a born again believer, we cannot make a premature judgment that he or she is demonized or even demon possessed. The real problem may be psychosomatic illness, rather than demonization or demon possession. Dr. Archibald Hart, a professor of the School of Psychology at Fuller Theological Seminary, has alerted that schizophrenia, which is psycho-somatic disease due to a defect in a brain chemistry, may exhibit bizarre symptoms which are frequently found in the demon possession such as, social isolation and withdrawal; digressive, vague, over-elaborate

92 Nigel G. Wright, "Charismatic Interpretation of the Demonic," in The Unseen World, edited by Anthony N. S. Lane (Grand Rapids, MI: Baker Book, 1996), 156.

93 See George Eldon Ladd, A Theology of New Testament, revised and edited by Donald A. Hagner (Grand Rapids, MI: Wm. B. Eerdmands Publishing Co., 1994), 499-520; David E. Aune, "Human Nature and Ethics in Hellenistic Philosophical Traditions and Paul: Some Issues and Problems, in Paul and His Hellenistic Context, edited by Troels Engberg-Pedersen (Minneapolis: Fortress Press, 1995), 298-305; James D.G. Dunn, The Theology of Paul the Apostle (Grand Rapids, MI: Wm. B. Eerdmans Publishing Co., 1998), 51-78 for a detailed exposition on this subject. 
conversation, or lack conversation, or lack of content in conversation; unusual experiences (recurrent illusions, sensing the presence of a force or person not actually present); or even revulsion to Christian symbols (the cross, the Bible, and other Christian symbols).94 A similar caution has also been raised by Dr. Jerry Mungadze, a specialist in the treatment of Dissociative Identity Disorders (DID).

..., it is important to emphasize that we are already dealing with a diagnosed DID client who claims demonization which is commonly referred to as demon possession. Dissociative symptoms such as depersonalization, trancing, amnesia, and fluctuation of skills, change in voice, behavior, and personality can be mistaken for demonization or possession. Therefore, it is imperative that a DID client claiming demonization needs symptom evaluation to assure that what they are reporting as spiritual is not just another manifestation of dissociative symptoms.95

Furthermore, human being is not only complex; he or she is also ambiguous. "The 'I' is divided," writes James D.G. Dunn. "It is the 'I' that wants to do good and to avoid doing evil; but it is the same 'I' which fails to do good and commits the evil (Rom 7.18-19). The culprit is sin; it enslaves the fleshy 'I' and thus prevents the willing 'I' from achieving what it wills (7.20)."96 This ambiguity emerges due to the fact that there is overlapping between the present age and the age to come or the tension between the already' and 'not yet'. Thus, it is true that believers have 'already' experienced the life of the age to come through the death of Christ and the gift of the Spirit, but it is also equally true that they have not been removed from the realm of the flesh. They are still en sarki, "living in the present body of humiliation subject to realities of the present age."97 Therefore

94 Archibald D. Hart, “Regeneration, Deliverance or Therapy?” Leadership (Summer 1991): 74-76.

95 Jerry Mungadze, "Is it Dissociation or Demonization? Sorting Out Spiritual and Clinical Issues in the Treatment of Dissociative Disorders," Journal of Psychology and Christianity (Summer 2000): 142.

96 Dunn, 473-74. 
until "the perfect" comes, believers live in a constant struggle with the power of $\sin$.

The implication of such understanding is far-reaching. First, we cannot simply say that salvation is a matter of "getting in" without any possibility of "getting out" - "once saved, always saved." Salvation, writes Gordon D. Fee, "has to do with both getting in and staying in."98 To be staying in the believer must work out his or her own salvation with fear and trembling (Phil. 3:12) by keeping his or her in steps with the Spirit and rejecting to live according to the flesh (kata sarka). Failure to keep 'staying in' results in the repulsion of the Spirit of Christ and loss of salvation. When the Spirit does not indwell within the believer anymore, the 'other spirits' may invade and possess him or her. This understanding may serve as a theological explanation behind a person who once showed signs of being a born-again believer and later manifest signs of demon possession.

Secondly, the coming of the age to come through the death of Christ and the gift of the Spirit indeed has brought an unrecoverable wound to the kingdom of darkness. However, such kingdom is not totally destroyed until the "perfect" comes. This consequently opens the possibilities of demonic attack upon the lives of believers. The vivid example for this is Paul's "thorn in the flesh experience" (2 Cor. 12: 7). Thus, it is clear that life in the Spirit does not exclude the demonic attack. However to say that such a demonic attack is identical with demonized or demon-possession is going too far. 


\section{CONCLUSION}

In conclusion, we can say that the Third Waver's arguments as support for the assertion that a born-again believer can be demon-possessed or demonized have been biblically and theologically questionable. Therefore, it is better to consider their interpretation an "observation," rather than a theological interpretation of the demonic.

As final words, it is worth to listen to Nigel Wright's constructive analysis and critique on modern charismatic (sic. the third wavers) approaches to the demonic:

Two extremes should be avoided: the naturalist which would reduce the whole of these phenomena to a materialist explanation and the supernaturalist which allows only of one interpretation: demons. Instead it should be recognized that human beings are complex both in the ways in which they are consciously and unconsciously related to one another, Once it is acknowledged that human beings are psychologically, socially, psychically and spiritually complex, we are encouraged to be more cautious about the ways in which we might interpret what is taking place before our very eyes.99

Let those who have ears listen! 


\section{AFTERWORDS}

An ordained Lutheran minister and professor of theology at the University of Vienna, Suzanne Heine, says " The rise of heretical group is always a sign that orthodoxy has become heretical."100 In other words, as Charles Hummel says, "history shows that most basic doctrinal deviation arises from the church's denial of biblical truth - in practice if not in preaching. Effort to remedy this lack then send the pendulum to an opposite extreme."101

It is a fact that demonology has been neglected for many years. The greatest theologian of 20th century, Karl Barth, for example, in his magnum opus, Church Dogmatics, only devotes a relatively "tiny space" on this topic.102 Classical Pentecostals theologians are guilty of the same fault. They seem to be preoccupied with their theological distinctive, viz., Baptism in the Holy Spirit as a distinct from and subsequent experience to conversion with speaking in tongues as its physical evidence. As, Wonsuk Ma says,

Two traditionally neglected areas of systematic theology have been demonology and angelology. It could be argued that Pentecostals have been in a good position to these theological categories, given their experiential relationship to the Holy Spirit, their insights into the spiritual world, and their keen awareness of the spiritual forces at work, especially in human affairs. In fact, testimonies of supernatural power encounters characterize Pentecostal mission. However, Pentecostals have been slow to make theological contributions to these areas of demons and angels and how they relate to human life. 1990), 76.

100As quoted by Donald G. Bloesch, "The Father and the Goddess," Christianity Today (October 8,

101 Charles E. Hummel, Fire in the Fire Place: Charismatic Renewal in the Nineties (Downers Grove, IL: IVP, 1993).

102 Karl Barth, Church Dogmatics: The Doctrine of Creation, translated by G.W. Bromiley and R. J. Egrlich (Edinburgh: T \& T Clark, 1983), III.3: 519-31. 
Even a little exercise in drawing empirical generalizations from their own experiences could have contributed to an understanding of spiritual warfare. 103

As a result of this neglect, there has been "theological vacuum" in the area of demonology and angelology. Hiebert calls such a situation, "the flaw of the excluded middle."104 Dickason, Peter Wagner, Kraft and others certainly concern for this theological vacuum. This has motivated them to develop such a demonology that is able to answer satisfactorily the demand of pastoral works and mission field in the post-modern age. Inspite of being biblically and theologically inadequate, their works in some degree have helped some people to cope with their personal and social pains.

Therefore, it is not enough to point out the biblical error or exegetical fallacies of Third Wave' interpretation of the demonic; we need to acknowledge our ignorance on this area in the past and then begin putting much effort to produce demonology which is faithful to biblical testimonies and relevant to our contemporary situations. Only by so doing, we can avoid two kinds of error mentioned in C.S. Lewis' Screwtape Letters

There are two equal and opposite errors into which our race can fall about the devils. One is to disbelieve in their existence. The other is to believe, and to feel an excessive and unhealthy interest in them. They themselves are equally pleased by both errors and hail a materialist or a magician with the same delight. 105

\section{BIBLIOGRAPHY}

Arnold, Clinton E. Three Crucial Questions about Spiritual Warfare. Grand Rapids, MI: Baker Book, 1997.

103Wonsuk Ma, “A 'First Waver' Looks at the 'Third Wave': A Pentecostal Reflection on Charles Kraft's Power Encounter Terminology,” Pneuma (Fall 1997): 198-99.

104 Hiebert, 196.

105 C.S. Lewis, The Screwtape Letters (London: Fontana Books, 1942), 9. 
Aune, David E. "Human Nature and Ethics in Hellenistic Philosophical Traditions and Paul: Some Issues and Problems," in Paul and His Hellenistic Context. Edited by Troels Engberg-Pedersen. Minneapolis: Fortress Press, 1995.

Barret, Charles K. The Second Epistle to the Corinthians. New York: Harper and Row, 1973.

Barrett, David B., and Todd M. Johnson, "Annual Statistical Table on Global Mission: 2000," International Bulletin 50th Anniversary (January 2000): 25

Barth, Karl. Church Dogmatics: The Doctrine of Creation, translated by G.W. Bromiley and R. J. Ehrlich. Edinburgh: T \& T Clark, 1983.

Bloesch, Donald G. "The Father and the Goddess," Christianity Today (October 8, 1990): 74-76.

Bultmann, Rudolf. "New Testament and Mythology," in Keryma and Myth. Edited by H. W. Bartsch and Revised by Reginald H. Fuller, 1-44. London, UK: SPCK, 1961.

Burgess, Stanley M. The Spirit and the Church: Antiquity. Peabody, MA: Hendrickson Publishers, 1984

Carter, Stephen, "Demon Possession and Christian," Asia Journal of Pentecostal Theology (January 2000): 19-31.

Collins, W. Duane. "An Assemblies of God Perspective on Demonology Part II." Paraclete 28:1 (Winter 1994): 18-22. 
Dickason, Fred C. Demon Possession and the Christian. Wheaton, IL: Crossway Books, 1987.

Dunn, James D. G. The Theology of Paul, the Apostle. Grand Rapids, MI: Wm. B. Eerdmans Publishing Co., 1998.

Fee, Gordon D. Paul, Spirit, and the People of God. Peabody, MA: Hendrickson, Publisher, 1996.

Grudem, Wayne E. Systematic Theology: An Introduction to Biblical Doctrine. Grand Rapids, MI: Zondervan Publishing House, 1994.

Hart, Archibald D. "Regeneration, Deliverance or Therapy?” Leadership (Summer 1991): 72-79.

Hiebert, Paul G. Anthropological Reflections on Missiological Issues. Grand Rapids, MI: Baker Book, 1994.

Hummel, Charles E. Fire in the Fire Place: Charismatic Renewal in the Nineties. Downers Grove, IL: IVP, 1993.

Hunt, Stephen. "Deliverance: The Evolution of a Doctrine." Themelios (October 1995): 10-13.

Koch, Kurt. Occult Bondage and Deliverance: Advice for Counseling the Sick, the Troubled, and the Occult Oppressed. Grand Rapids, MI: Kregel Publication, 1970.

Kraft, Charles H. Defeating the Dark Angels. Ann Arbor, MI: Servant Publication, 1992. 
Ladd, George Eldon. A Theology of the New Testament. Revised and Edited by Donald A. Hagner. Grand Rapids, MI: Wm. B. Eerdmans Publishing Co., 1994.

Lane, William L. The Gospel According to Mark. New International Commentary on the New Testament, Edited by F.F. Bruce. Grand Rapids, MI: Wm. B. Eerdmans Publishing Co., 1974.

Lewis, C.S. The Screwtape Letters. London, UK: Fontana Books, 1942.

Ma, Wonsuk. "A 'First Waver' Looks at the 'Third Wave': A Pentecostal Reflection on Charles Kraft's Power Encounter Terminology.” Pneuma (Fall 1997): 189-206.

Martin, Ralph P. 2 Corinthians. WBC. Waco, TX: Word Book, Publisher, 1986.

McGrath, Alister. The Genesis of Doctrine: A Study in the Foundation of Doctrinal Criticism. Grand Rapids, MI: Wm. B, Eerdmans, 1997.

Menzies, William W. Anointed to Serve. Springfield, MO: Gospel Publishing House, 1971.

. "The Methodology of Pentecostal Theology: An Essay on Hermeneutics," in Essay on Apostolic Themes: Studies in Honor of Howard M. Ervin Presented to him by Colleagues and Friends on his Sixty-Fifth Birthday. 1-14. Edited by Paul Elbert. Peabody, MA: Hendrickson Publishers, 1985..

Montgomery, John W. "Commentary on Hysteria and Demons, Depression and Oppression, Good and Evil." In Demon Possession edited by John W Montgomery, 232-36. Minneapolis, MN: Bethany House Publishers, 1976.

Mungadze, Jerry. "Is it Dissociation or Demonization? Sorting Out Spiritual and 
Clinical Issues in the Treatment of Dissociative Disorders." Journal of Psychology and Christianity (Summer 2000): 139-143.

Penn-Lewis. Jesse. War on the Saints. 9th ed. New York: Thomas Lowe, 1973.

Pluss, Jean-Daniel. Therapeutic and Prophetic Narratives in Worship. Studies in the Intercultural History of Christianity Band 54. Frankurt: Verlag Peter Lang, 1988.

Seel, John. The Evangelical Forfeit. Grand Rapids, MI: Baker Book, 1993.

Subritzky, Bill. Demons Defeated .Chichester: Sovereign World, 1986.

Unger, Merril F. What Demon Can Do to Saints. Chicago, IL: Moody Press, 1991.

Wagner, C. Peter. The Third Wave of the Holy Spirit: Encountering the Power of Signs and Wonders Today. Ann Arbour: Vine Books, 1988.

Walker, Andrew. "The Devil You Think You Know" in Charismatic Renewal, 86105. Edited By Tom Smail, Andrew G. Walker, and Nigel G. Wright. London: SPCK, 1995.

Wright, Nigel G. "Charismatic Interpretation of the Demonic." In The Unseen World, edited by Anthony N.S. Lane, 149-164. Grand Rapids, MI: Baker Book, 1996. 